\title{
SEROPREVALENCE OF HEPATITIS B VIRUS INFECTION IN INDIVIDUALS WITH CLINICAL EVIDENCE OF HEPATITIS IN GOIÂNIA, GOIÁS. DETECTION OF VIRAL DNA AND DETERMINATION OF SUBTYPES
}

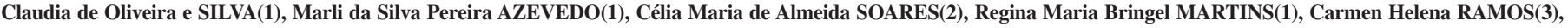
Roberto Ruhman DAHER(1) \& Divina das Dôres de Paula CARDOSO(1)

\begin{abstract}
SUMMARY
The presence of serological markers for hepatitis B virus (HBsAg, anti-HBc IgM and Anti-HBc total) was investigated in the serum of 1,396 individuals who had clinical suspect of hepatitis. It was observed that $50.7 \%$ of the individuals were positive and, from the total of the studied individuals, $14.5 \%$ were positive for HBsAg. From these, $8.5 \%$ were also positive for anti-HBc IgM. The analysis in relation to gender showed a higher seroprevalence index among male individuals $(\mathrm{p}<0.0001)$. It was observed the occurrence of subtypes adw $(62.7 \%)$, ayw ay $_{3}(23.5 \%)$, ayw 2 (9.8\%) and $\operatorname{adw}_{4}(3.9 \%)$. The viral DNA was detected in 61 (33.9\%) $\mathrm{HBsAg}$ positive samples and in one sample positive only for anti-HBc total. These results indicate an important incidence of the HBV infection in this population, and reinforce previous studies regarding this virus in the central west region of Brazil.
\end{abstract}

KEYWORDS: Hepatitis B; HBV-DNA; Subtypes.

\section{INTRODUCTION}

The hepatitis B virus (HBV) is disseminated throughout the human population and it is estimated that there are over 350 million chronic carriers of the virus, which represents approximately $5 \%$ of the world population $^{22}$. The virus may cause in the host both asymptomatic and symptomatic infection and the disease might evolve to cirrhosis and hepatocelular carcinoma ${ }^{24,33}$. The HBV presents genetic variability that is demonstrated by the occurrence of subtypes and genotypes which present different distribution in relation to the geographical area ${ }^{2,12,23}$. Several investigations have been made regarding HBV aiming at the characterization of the positive samples for the virus, since this procedure is also useful in the comprehension of the development of the infection $^{21,42}$

In Goiânia-Goiás, studies about HBV seroprevalence have been developed and the important spreading of the agent in this region has been demonstrated $d^{3,4,6,7,32,39}$. However, there is no data regarding this virus in population that presents clinical suspect of hepatitis. This study aims at the detection of serological markers for HBV and the viral DNA, as well as the determination of HBV subtypes in this population group.

\section{MATERIAL AND METHODS}

Studied population: From August 1995 to July 1997, 1,396 blood samples were obtained from equal number of patients with clinical evidence of hepatitis which attended the health public system of Goiânia-
GO. The clinical suspect of hepatitis included at least one of the following characteristics (linked epidemiological data): low fever, jaundice, gastric intestinal symptoms (nausea and vomit) and elevations of serum aminotransferase activities. From this population, 897 were male and 499 female.

\section{METHODOLOGY}

1 - Detection of serological markers for HBV: The 1,396 blood samples were tested aiming at the detection of hepatitis B surface antigen ( $\mathrm{HBsAg}$ ), IgM antibodies to hepatitis B core antigen (anti-HBc $\operatorname{IgM}$ ) and total antibodies to hepatitis B core antigen (anti-HBc total). For this procedure enzyme immunoassay (EIE) commercial kits were used (Hepanostika-Organon Teknika B.V., Boxtel, Netherlands). The assays were performed as described by the manufacturers.

2 - Subtyping of the HBsAg positive samples: The HBsAg positive samples were titled by reverse passive hemaglutination (Biomanguinhos/ Fiocruz/Rio de Janeiro/Brazil) and the samples that presented a title equal or higher than 28 hemaglutination units were subtyped by radial immunodiffusion. The samples that presented a title between 24 and 28 units were analyzed by EIE with monoclonal antibodies. All immunobiologicals used in both assays were prepared and supplied by the Center of National Reference in Viral Hepatitis/Oswaldo Cruz Foundation/Rio de Janeiro-RJ/Brazil.

3 - DNA detection: The HBsAg positive samples were tested by

(1) Instituto de Patologia Tropical e Saúde Pública, Universidade Federal de Goiás, Goiânia, GO, Brasil.

(2) Laboratório de Biologia Molecular, ICB2, Campus II, Universidade Federal de Goiás, Goiânia, GO, Brasil

(3) Laboratório Central de Saúde Pública Dr. Giovanni Cysneiros.

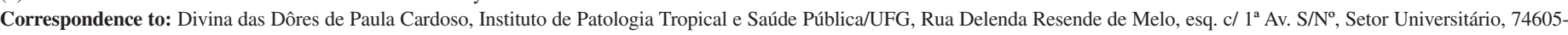
050 Goiânia, Goiás, Brasil. Phone: +55-62-2096122, Fax: +55-62-2023066. E-mail: divinaufg@bol.com.br 


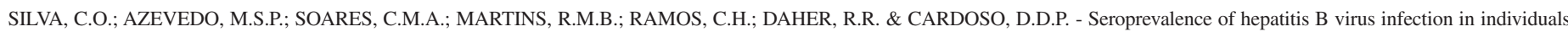
with clinical evidence of hepatitis in Goiânia, Goiás. Detection of viral DNA and determination of subtypes. Rev. Inst. Med. trop. S. Paulo, 44(6):331-334, 2002.

two methodologies for detection of viral DNA: 85 were tested by molecular hybridization (Dot-blot) and 95 by polymerase chain reaction (PCR). Moreover, 28 positive samples for Anti-HBc total and negative for HBsAg were also tested by PCR. The methodology of Dot-blot was performed in agreement with NIEL et al. (1994) $)^{28}$ with modifications. The probe was labelled with $\left.{ }^{32} \mathrm{P}\right]$ dATP using the kit Megaprime DNA labeling system RPN 1604 (Amershan Biosciences, Buckinghamshire, UK).

For the PCR procedure, the DNA was extracted from serum samples and amplified according to description of NIEL et al. $(1994)^{28}$. First, the samples were tested using 5 pairs of primers for the conserved areas of genome (PS1-PS2, X1-X2, C1-C2, C1-PS2 and PS1-S2). The negative samples in this first stage, were then submitted to the semi-nested PCR, using the pairs of primers PS1-PS2 and PS4-S2 ${ }^{15,28}$. The PCR procedure utilized is able to detect 100 copies per genome (Gomes, S.A. - personal communication).

\section{RESULTS}

1 - Seroprevalence: It was observed a seroprevalence index of $50.7 \%$ (HBsAg/anti-HBc IgM; HBsAg/anti-HBc total; anti-HBc total). From the total of 1,396 individuals, $14.5 \%$ were positive for $\mathrm{HBsAg}$ and $8.5 \%$ were also positive to anti-HBc IgM (Table 1). Moreover, from the 897 male individuals, $60.1 \%$ were positive in relation to $33.9 \%$ of the female individuals $(\mathrm{p}<0.0001)$ (Table 2).

Table 1

Distribution of hepatitis B virus positive serum samples, obtained from individuals with clinical evidence of hepatitis, in relation to the serological markers

\begin{tabular}{lrc}
\hline & $\mathrm{N}$ & $\%^{*}$ \\
\hline HBsAg/ anti-HBc IgM & 119 & 8.5 \\
HBsAg/ anti-HBc total & 83 & 6.0 \\
Anti-HBc total & 506 & 36.2 \\
\hline Total & 708 & 50.7
\end{tabular}

*Index calculated in relation to the 1,396 blood samples analyzed; N- number of positive samples.

Table 2

Distribution of hepatitis B virus positive samples obtained from individuals with clinical evidence of hepatitis, in relation to the gender

\begin{tabular}{lcc}
\hline & Positives/Total & $\%$ \\
\hline Male $^{*}$ & $539 / 897$ & 60.1 \\
Female & $169 / 499$ & 33.9 \\
\hline Total & $708 / 1396$ & 50.7 \\
\hline
\end{tabular}

$* \mathrm{X}^{2}=88.2 \mathrm{p}<0.0001$

2 - Subtyping: From the subtyped samples, 32 (62.7\%) were $\mathrm{adw}_{2}$, $12(23.5 \%)$ ayw $_{3}$ and the remaining samples were ayw $2(9.8 \%)$ and $\mathrm{adw}_{4}$ $(3.9 \%)$. The analysis in relation to the year shows that the subtype adw occurred throughout the years of study, while the subtypes ayw ${ }_{3}$ and adw $_{4}$ occurred only during the year of 1996 and the ayw ${ }_{2}$ in 1995 and in 1996 (Table 3).

332
Table 3

Distribution of HBsAg subtypes from 51 hepatitis B virus positive samples obtained from individuals of Goiânia-Goiás in relation to the year of collection

\begin{tabular}{cccccc}
\hline Year & $\mathrm{adw}_{2}$ & $\mathrm{ayw}_{3}$ & $\mathrm{ayw}_{2}$ & $\mathrm{adw}_{4}$ & Total \\
\hline 1995 & 10 & - & 01 & - & 11 \\
1996 & 11 & 12 & 04 & 02 & 29 \\
1997 & 11 & - & - & - & 11 \\
\hline Total & 32 & 12 & 05 & 02 & 51 \\
& $(62.7 \%)$ & $(23.5 \%)$ & $(9.8 \%)$ & $(3.9 \%)$ & $(100.0 \%)$ \\
\hline
\end{tabular}

3 - Detection of viral DNA: Positivity indexes of $35.3 \%$ and $32.6 \%$ were observed for viral DNA using the methodologies of Dot-blot and PCR respectively (Table 4). From the 28 negative serum samples for $\mathrm{HBs} \mathrm{Ag}$ and positive for anti-HBc total, one was positive for viral DNA.

Table 4

Detection of HBV-DNA by Dot-blot and PCR methodologies, in relation to the serological markers, in individuals with clinical evidence of hepatitis from Goiânia-Goiás

\begin{tabular}{lcccc}
\hline & \multicolumn{2}{c}{ Dot-blot } & \multicolumn{2}{c}{ PCR } \\
& $\mathrm{N}$ & $(\%)$ & $\mathrm{N}$ & $(\%)$ \\
\hline HBsAg/anti-HBc IgM & $19 / 42$ & $(45.2)$ & $19 / 64$ & $(29.7)$ \\
HBsAg/anti-HBc total & $11 / 43$ & $(25.6)$ & $12 / 31$ & $(38.7)$ \\
\hline Total & $30 / 85$ & $(35.3)$ & $31 / 95$ & $(32.6)$ \\
\hline
\end{tabular}

$\mathrm{N}$ - number of positive samples/ number of tested samples

It was also observed that the pair $\mathrm{C} 1-\mathrm{C} 2$ presented the highest index $(21.6 \%)$ of detection of the viral DNA followed by X1-X2 (12.6\%) and PS1-PS2 (11.6\%).

\section{DISCUSSION}

Although there are many epidemiological surveys regarding HBV seroprevalence reported in literature, the occurrence of HBV in clinical cases of hepatitis has been poorly documented. In this way, few studies have been carried out with population similar to this study. In a study by CASEY et al. (1996) ${ }^{9}$ performed in Peru, a seroprevalence index of $100 \%$ was observed. In the present study, a global index of $50.7 \%$ of $\mathrm{HBV}$ seropositivity was detected. Comparing this result with data from the literature, concerning other population, it was observed that this index is higher than several other indexes detected in different parts of the world ${ }^{1,8,13,20}$, including Goiânia-Goiás s,6,32 $^{3,}$

The analysis of the distribution of the serological markers for HBV shows that $14.5 \%$ of the individuals were positive for $\mathrm{HBsAg}$ and $8.5 \%$ were also positive for anti-HBc IgM, which indicates not only the condition of carriers of the virus, but also acute infection. These indexes were higher when compared to studies accomplished in different areas of the world with populations different from this study ${ }^{20,37,40}$, the same occurring in Brazil ${ }^{30,36}$, including Goiânia-Goiás ${ }^{4,34,39}$. Also, it was 


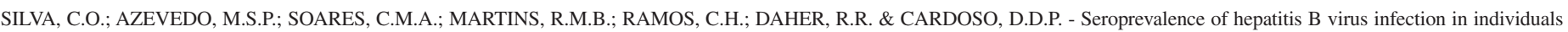
with clinical evidence of hepatitis in Goiânia, Goiás. Detection of viral DNA and determination of subtypes. Rev. Inst. Med. trop. S. Paulo, 44(6):331-334, 2002.

observed that other studies accomplished with similar population presented higher HBsAg indexes of detection, such as $59.3 \%$ in patients with hepatocarcinoma in Nigeria $^{31}, 60.0 \%$ in patients with acute hepatitis in Somalia ${ }^{29}$ and $88.0 \%$ in military recruits from Peru'.

The data showed higher detection of HBV (60.1\%) among male individuals, which was also demonstrated by other studies ${ }^{1,26}$.

In this study it was observed a predominance of the subtype $\mathrm{adw}_{2}$ followed by ayw ${ }_{3}$, which is in agreement with other studies ${ }^{14,39}$, and supports previous results that have demonstrated a higher prevalence of these subtypes during the last decade in the region of Goiânia, Goiás, Brazil $^{14}$.

Indexes of viral DNA detection of $35.3 \%$ and $32.6 \%$ were observed by Dot-blot and PCR, respectively. These results are in agreement with the studies accomplished by TEDESCHI et al. (1989) ${ }^{38}$ and CHIARAMONTE et al. (1991) $)^{11}$ although they differ from other studies in which it has been observed higher indexes of detection for HBVDNA by PCR $^{2,16,27}$ and Dot-blot ${ }^{26}$.

A higher detection of the viral DNA was observed when the C1-C2 primer pair was used, and this fact is in agreement with previous study ${ }^{15}$. Although some studies have been observed the occurrence of mutations in the genomic area Pre-C/C $\mathrm{C}^{21,43}$, it is assumed that it is a conserved genomic are ${ }^{17}$ and, in this way, the present study confirmed the effectiveness of this pair of primers for HBV-DNA detection.

From the 28 anti-HBc total positive samples tested by PCR, one was positive. Some reports have shown the detection of the HBV-DNA by PCR in individuals positive for anti-HBc total/ anti-HBs, and even in individuals without any serological marker for the infection ${ }^{15,35,41}$ and some explanations have been proposed to elucidate this condition ${ }^{5,18,19,43}$. In any case, this fact supports the importance of screening by anti-HBc at the blood banks from all areas of the world and point out the requirement of improving the screening methods used for viral detection $^{10,15,25,35}$.

\section{ACKNOWLEDGMENTS}

We are grateful to the Center of National Reference in Viral Hepatitis/ Oswaldo Cruz Foundation/Rio de Janeiro-RJ/Brazil for supplying the immunobiologicals used in the EIE and subtyping assays, and to FUNAPE/UFG for providing financial support.

\section{RESUMO}

\section{Soroprevalência da infecção pelo vírus da hepatite B em indivíduos com evidência clínica de hepatite em Goiânia, Goiás. Detecção do DNA viral e determinação dos subtipos}

Investigou-se a presença dos marcadores sorológicos AgHBs, anti$\mathrm{HBc} \operatorname{IgM}$ e anti-HBc total no soro de 1.396 indivíduos com suspeita clínica de hepatite. Observou-se uma soroprevalência para a infecção pelo VHB de 50,7\%, sendo que do total dos 1.396 indivíduos, 14,5\% eram positivos para AgHBs e 8,5\% eram também positivos para anti$\mathrm{HBc}$ IgM, tendo ainda sido observado que a soroprevalência foi maior em indivíduos do sexo masculino $(\mathrm{p}<0,0001)$. Por subtipagem foram identificados os seguintes subtipos: $\operatorname{adw}_{2}(62,7 \%)$, ayw $3(23,5 \%)$, ayw 2 $(9,8 \%){\text { e } \operatorname{adw}_{4}}_{4}(3,9 \%)$. O DNA viral foi detectado em 61 (33,9\%) amostras positivas para o AgHBs e em uma amostra positiva somente para anti$\mathrm{HBc}$ total. Estes resultados indicam importante índice de ocorrência da infecção pelo VHB nesta população e reforça dados de estudos anteriores a respeito da importante circulação do vírus na região Centro-Oeste do Brasil.

\section{REFERENCES}

1. ALMOG, R.; LOW, M.; COHEN, D. et al. - Prevalence of anti-hepatitis A antibodies, hepatitis B viral markers, and anti-hepatitis C antibodies among immigrants from the former USSR who arrived in Israel during 1990-1991. Infection, 27: 212-217, 1999.

2. ARAUZ-RUIZ, P.; NORDER, H.; VISONA, K.A. \& MAGNIUS, L.O. - Genotype F prevails in HBV infected patients of Hispanic origin in Central America and may carry the precore stop mutant. J. med. Virol., 51: 305-312, 1997.

3. AZEVEDO, M.S.P.; CARDOSO, D.D.P.; MARTINS, R.M.B. et al. - Rastreamento sorológico para hepatite $\mathrm{B}$ em profissionais de saúde na cidade de Goiânia-Goiás. Rev. Soc. bras. Med. trop., 23: 157-162, 1994.

4. BORGES, A.M.T.; AZEVEDO, M.S.P.; MARTINS, R.M.B. et al. - Hepatite B em pacientes de centros de diálise de Goiânia - Goiás. Rev. Pat. trop., 26: 9-16, 1997.

5. CACCIOLA, I.; POLKICCINO, T.; SQUADRITO, G. et al. - Occult hepatitis B virus infection in patients with chronic hepatitis $C$ liver disease. New Engl. J. Med., 341: 22-26, 1999.

6. CARDOSO, D.D.P.; AZEVEDO, M.S.P.; MARTINS, R.M.B. et al. - Soroprevalência para a infecção pelo vírus da hepatite B pelos marcadores AgHBs e anti-HBs em população feminina na área urbana de Goiânia-GO. Rev. Pat. trop., 19: 135-141, 1990.

7. CARDOSO, D.D.P.; FARIA, E.L.; AZEVEDO, M.S.P. et al. - Soroepidemiologia para o vírus da hepatite B (VHB) em gestantes/parturientes e sua transmissão para recémnascidos em Goiânia-GO. Rev. Soc. bras. Med. trop., 29: 349-353, 1996.

8. CARVALHO, H.B.; MESQUITA, F.; MASSAD, E. et al. - HIV and infections of similar transmission patterns in a drug injectors community of Santos, Brazil. J. AIDS hum. Retrov., 12: 84-92, 1996.

9. CASEY, J.L.; NIRO, G.A.; ENGLE, R.E. et al. - Hepatitis B virus (HBV)/hepatitis D virus (HDV) coinfection in outbreaks of acute hepatitis in the Peruvian Amazon basin: the roles of HDV genotype III and HBV genotype F. J. infect. Dis., 174: 920926, 1996.

10. CHEMIN, I.; BAGINSKI, I.; PETIT, M.A. et al. - Correlation between HBV DNA detection by polymerase chain reaction and Pre-S1 antigenemia in symptomatic and asymptomatic hepatitis B virus infections. J. med. Virol., 33: 51-57, 1991.

11. ChIARAMONTE, M.; STROFFOLINI, T.; NGATCHU, T. et al. - Hepatitis B virus infection in Cameroon: a seroepidemiological survey in city school children. J. med. Virol., 33: 95-99, 1991.

12. COUROUCÈ-PAUTY, A.M.; PLANÇON, A. \& SOULIER, J.P. - Distribution of HBsAg subtypes in the world. Vox Sang. (Basel), 44: 197-211, 1983.

13. FOCACCIA, R.; CONCEIÇÃO, O.J.G.; SETTE Jr., H. et al. - Estimated prevalence of viral hepatitis in the general population of the municipality of São Paulo, measured by a serologic survey of a stratified, randomized and residence-based population. Braz. J. infect. Dis., 2: 269-284, 1998.

14. GASPAR, A.M.C. \& YOSHIDA, C.F.T. - Geographic distribution of HBsAg subtypes in Brazil. Mem. Inst. Oswaldo Cruz, 82: 253-258, 1987.

15. GOMES, S.A.; YOSHIDA, C.F.T. \& NIEL, C. - Detection of hepatitis B virus DNA in hepatitis B surface antigen-negative serum by polymerase chain reaction: evaluation 
SILVA, C.O.; AZEVEDO, M.S.P.; SOARES, C.M.A.; MARTINS, R.M.B.; RAMOS, C.H.; DAHER, R.R. \& CARDOSO, D.D.P. - Seroprevalence of hepatitis B virus infection in individuals with clinical evidence of hepatitis in Goiânia, Goiás. Detection of viral DNA and determination of subtypes. Rev. Inst. Med. trop. S. Paulo, 44(6):331-334, 2002.

of different primer pairs and conditions. Acta virol., 40: 133-138, 1996.

16. HARDIE, D.R.; KANNEMEYER, J. \& STANNARD, L.M. - DNA single strand conformation polymorphism identifies five defined strains of hepatitis B virus (HBV) during an outbreak of HBV infection in an oncology unit. J. med. Virol., 49: 49-54, 1996.

17. HAWKINS, A.E.; GILSON, R.J.C.; BICKERTON, E.A.; TEDDER, R.S. \& WELLER, I.V.D. - Conservation of precore and core sequences of hepatitis B virus in chronic viral carriers. J. med. Virol., 43: 5-12, 1994.

18. HOLLINGER, F.B. - Hepatitis B virus. In: FIELDS, B.N.; KNIPE, D.M. \& HOWLEY, P.M. Fundamental virology. 3. ed. Philadelphia, Lippincott/Raven, 1996. p. 27392807.

19. KARTHIGESU, V.D.; ALLISON, L.M.C.; FERGUSON, M. \& HOWARD, C.R. - A hepatitis B virus variant found in the sera of immunized children induces a conformational change in the HBsAg "a" determinant. J. med. Virol., 58: 346-352, 1999.

20. LEON, P.; VENEGAS, E.; BENGOECHEA, L. et al. - Prevalence of infections by hepatitis B, C, D and E viruses in Bolivia. Rev. panamer. Salud publ., 5: 144-151, 1999.

21. LINDH, M.; GUSTAVSON, C.; MARDBERG, K. et al. - Mutation of nucleotide 1,762 in the core promoter region during hepatitis $\mathrm{B}$ e seroconversion and its relation to liver damage in hepatitis B e antigen carriers. J. med. Virol., 55: 185-190, 1998.

22. MADDREY, W.C. - Hepatitis B: an important public health issue. Clin. Lab., 47: 51-55, 2001.

23. MAGNIUS, L.O. \& NORDER, H. - Subtypes, genotypes and molecular epidemiology of the hepatitis B virus as reflected by sequence variability of the S-gene. Intervirology, 38: 24-34, 1995.

24. MARGOLIS, H.S.; ALTER, M.J. \& HADLER, S.C. - Hepatitis B: evolving epidemiology and implications for control. Semin. Liver Dis., 11: 84-92, 1991.

25. MARTELLI, C.M.T.; ANDRADE, A.L.S.S.; CARDOSO, D.D.P.; SILVA, S.A. \& ZICKER, F. - Considerações metodológicas na interpretação do rastreamento sorológico da hepatite B em doadores de sangue. Rev. Saúde públ. (S. Paulo), 25: 11-16, 1991.

26. McINTOSH, E.D.G.; GIVNEY, R.; ZHANG, S.S. et al. - Molecular epidemiology and variation of hepatitis B in recent immigrant families to Australia. J. med. Virol., 56: 10-17, 1998.

27. MORAES, M.T.B.; NIEL, C. \& GOMES, S.A. - A polymerase chain reaction-based assay to identify genotype F of hepatitis B virus. Braz. J. med. biol. Res., 32: 45-49, 1999.

28. NIEL, C.; MORAES, M.T.B.; GASPAR, A.M.C.; YOSHIDA, C.F.T. \& GOMES, S.A. Genetic diversity of hepatitis B virus strains isolated in Rio de Janeiro, Brazil. J. med. Virol., 44: 180-186, 1994.

29. NUTI, M.; HARARE, O. \& THAMER, G. - The surface antigen (HBsAg) and the eantigen $(\mathrm{HBeAg})$ in Somalian patients with acute viral hepatitis. Trans. roy. Soc. trop. Med. Hyg., 73: 185-187, 1979.

30. OLIVEIRA, M.L.A.; BASTOS, F.I.; TELLES, P.R. et al. - Prevalence and risk factors for HBV, HCV and HDV infections among injecting drug users from Rio de Janeiro, Brazil. Braz. J. med. biol. Res., 32: 1107-1114, 1999.

31. OLUBUYIDE, I.O.; ALIYU, B.; OLALELYE, O.A. et al. - Hepatitis B and C virus and hepatocellular carcinoma. Trans. roy. Soc. trop. Med. Hyg., 91: 38-41, 1997.

32. PORTO, S.O.B.; CARDOSO, D.D.P.; QUEIRÓZ, D.A.O. et al. - Prevalence and risk factors for HBV infection among street youth in central Brazil. J. adolesc. HIth., 15: 577-581, 1994.

33. PURCELL, R.H. - The hepatitis viruses: an overview. In: NISHIOKA, K.; SUZUKI, H. MISHIRO, S. \& ODA, T. Viral hepatitis and liver disease. Tokyo, Springer Verlag, 1995.

34. ROSA, H.; COSTA, A.P.V.F.; FERRAZ, M.L. et al. - Association between leprosy and hepatitis B infection. A survey in Goiânia, central Brazil. Rev. Inst. Med. trop. S. Paulo, 34: 421-426, 1992.

35. SHIH, L.; SHEU, J.C.; WANG, J.T. et al. - Serum hepatitis B virus DNA in healthy HBsAg negative Chinese adults evaluated by polymerase chain reaction. J. med. Virol., 32: 257-260, 1990.

36. SOUTO, F.J.D.; FONTES, C.J.F. \& GASPAR, A.M.C. - Outbreak of hepatitis B virus in recent arrivals to the Brazilian Amazon. J. med. Virol., 56: 4-9, 1998.

37. STRUVE, J.; GIESECKE, J.; OLCEN, P.; VON SYDOW, M. \& WEILAND, O. Prevalence of hepatitis B virus markers in Sweden: a community-based serosurvey of 4,000 young Swedish adults. Amer. J. Epidem., 135: 409-417, 1992

38. TEDESCHI, M.V.; PADILLA, C.F.; CAMARGO, I.F. \& YOSHIDA, C.F.T. - Potential infectivity of blood from HBsAg asymptomatic carriers due to the presence of HBVDNA and comparison with other markers of HBV infection. Rev. Inst. Med. trop. S. Paulo, 31: 377-383, 1989.

39. TELES, S.A.; MARTINS, R.M.B; VANDERBORGHT, B. et al. - Hepatitis B virus: genotypes and subtypes in Brazilian hemodialysis patients. Artif. Organs, 23: 1074 $1078,1999$.

40. TRIKI, H.; SAID, N.; SALAH, A.B. et al. - Seroepidemiology of hepatitis B, C and delta viruses in Tunisia. Trans. roy. Soc. trop. Med. Hyg., 91: 11-14, 1997.

41. UCHIDA, T.; KANEITA, Y.; GOTOH, K. et al. - Hepatitis C virus is frequently coinfected with serum marker-negative hepatitis B virus: probable replication promotion of the former by the latter as demonstrated by in vitro cotransfection. J. med. Virol., 52: 399-405, 1997.

42. ZHANG, X.; ZOULIM, F.; HABERSETZER, F.; XIONG, S. \& TREPO, C. - Analysis of hepatitis B virus genotypes and pre-core region variability during interferon treatment of $\mathrm{HBe}$ antigen negative chronic hepatitis B. J. med. Virol., 48: 8-16, 1996.

43. ZUCKERMAN, A.J. \& ZUCKERMAN, J.N. - Molecular epidemiology of hepatitis B virus mutants. J. med. Virol., 58: 193-195, 1999.

Received: 25 May 2002

Accepted: 26 September 2002 